\title{
MODEL PERJANJIAN KAWIN YANG DIBUAT SETELAH PERKAWINAN BERLANGSUNG PASCA BERLAKUNYA PUTUSAN MAHKAMAH KONSTITUSI NOMOR 69/PUU-XIII/2015 ${ }^{1}$
}

\author{
Sonny Dewi Judiasih, Deviana Yuanitasari, Revi Inayatillah \\ Fakultas Hukum Univeristas Padjadjaran \\ Jalan Dipati Ukur No 35 Bandung \\ sonny@unpad.ac.id
}

\begin{abstract}
Abstrak
Perjanjian kawin merupakan perjanjian tentang aspek-aspek perkawinan yang timbul selama perkawinan berlangsung. Perjanjian kawin setelah keluarnya putusan MK No. 69/PUUXIII/2015 dapat dibuat sebelum, pada saat dan selama perkawinan berlangsung. Artikel ini menganalisis mengenai pengaturan mengenai perjanjian kawin setelah berlakunya putusan MK No69/PUU-XII/2015 dan merumuskan model perjanjian kawin yang dibuat setelah berlakunya putusan MK.

Metode yang digunakan adalah pendekatan yuridis normatif dan spesifikasi penelitian secara deskriptif analitis. Analisis data secara yuridis kualitatif.

Keluarnya putusan Mahkamah Konstitusi Nomor 69/PUU-XIII/2015 menentukan bahwa perjanjian kawin dapat dibuat sebelum, pada saat dan selama perkawinan berlangsung, dan terdapat beberapa format dari model perjanjian kawin yang dapat menjadi panduan bagi para notaris yang akan membuat akta perjanjian kawin dan terdapat pula surat edaran dari Dirjen Dukcapil terkait Pencatatan Pelaporan Perjanjian Perkawinan.
\end{abstract}

Kata Kunci: Perjanjian, Perjanjian Kawin

\footnotetext{
${ }^{1}$ Riset Kompetensi Dosen Universitas Padjadjaran - Hibah Internal Universitas Padjadjaran 2017 


\section{A. Pendahuluan}

Perkawinan ialah ikatan lahir batin antara seorang pria dan seorang wanita sebagai suami isteri dengan tujuan membentuk keluarga yang bahagia dan kekal berdasarkan Ketuhanan Yang Maha Esa. Salah satu akibat hukum yang timbul dari adanya perkawinan adalah terbentuknya harta benda perkawinan.

Ketentuan didalam UU Perkawinan menyatakan bahwa harta yang diperoleh dalam perkawinan akan menjadi harta bersama. Selanjutnya terhadap harta yang diperoleh sebelum perkawinan akan tetap menjadi harta asal dari masing-masing suami isteri dalam perkawinan. Ketentuan tersebut menggambarkan bahwa ada beberapa jenis harta dalam perkawinan yang masing-masing terpisah. Ketentuan pemisahan harta tersebut dapat dikecualikan dengan dibuatnya perjanjian kawin.

Perjanjian kawin sebagaimana ditawarkan di atas merupakan sebuah kekecualian dari aturan umum tentang perjanjian kawin yang ada dalam UU Perkawinan (Isnaeni, 2015).Perjanjian kawin merupakan perjanjian tentang aspekaspek perkawinan yang timbul selama perkawinan berlangsung (Li, 2014). Perkawinan merupakan kesetiaan/kebersamaan dari individuindividu yang setara. Oleh karena itu perjanjian yang dibuat dalam keluarga sebagai suatu perjanjian yang sah (Crotyy, 1999). Harta perkawinan adalah semua harta yang diperoleh oleh pasangan suami isteri dalam perkawinan, kecuali (Walker, 2015):

- Harta yang didapat dari hadiah

- Harta yang diperoleh sebelum perkawinan

- Harta yang diperoleh suami atau isteri setelah dibuat perjanjian pemisahan harta

- Harta yang tidak termasuk dalam harta yang diperjanjikan oleh para pihak suami-isteri.

Perjanjian kawin dibuat pada waktu atau sebelum perkawinan dilangsungkan. Kedua pihak atas perjanjian bersama dapat mengadakan perjanjian tertulis yang disahkan oleh pegawai pencatat perkawinan, setelah mana isinya berlaku juga terhadap pihak ketiga sepanjang pihak ketiga tersangkut. Perjanjian tersebut berlaku sejak perkawinan dilangsungkan. Selama perkawinan berlangsung perjanjian tersebut tidak dapat diubah, kecuali bila dari kedua belah oihak ada perjanjian untuk mengubah dan perubahan tidak merugikan pihak ketiga.

Pada hari kamis, tanggal 27 Oktober 2016 telah dikeluarkan Putusan Mahkamah Konstitusi Nomor 69/PUU-XIII/2015 terkait pengujian materil terhadap Pasal 29 ayat (1), ayat(2), dan ayat(4) Undang- 
UndangNomor1Tahun 1974 tentang

Perkawinan, dimana Mahkamah Konstitusi dalam putusannya menyatakan bahwa pada waktu sebelum dilangsungkan atau selama dalam ikatan perkawinan kedua belah pihak atas persetujuan bersama dapat mengajukan perjanjian tertulis yang disahkan oleh pegawai pencatat perkawinan atau notaris setelah mana isinya berlaku juga terhadap pihak ketiga sepanjang pihak ketiga tersangkut.Perubahan norma tersebut tentu saja menimbulkan berbagai aspek hukum yang harus disikapi oleh pihak-pihak yang berkepentingan, misalnya oleh para akademisi yang harus merubah cara pandang terhadap pergeseran normatersebut.

Demikian juga para notaris yang bergelut dalam kegiatan praktik yang seringkali berhadapan dengan para pemohon pembuatan perjanjian kawin. Yang tidak kalah penting adalah pihak Catatan Sipil dan KUA yang bertindak sebagai institusi pencatat dari keberadaan perjanjian kawin yang harus menyiapkan perangkat atau mekanisme terhadap pembuatan perjanjian kawin setelah perkawinan berlangsung. Demikian pula instansi Pengadilan Negeri maupun Pengadilan Agama yang juga harus menyiapkan perangkat dan mekanisme terhadap kemungkinan adanya gugatangugatan dari pihak ketiga yang merasa dirugikan dengan dibuatnya perjanjian kawin setelah perkawinan berlangsung.
Berdasarkan latar belakang di atas, maka dirumuskan permasalahan sebagai berikut:

1. Bagaimanakah pengaturan mengenai perjanjian kawin setelah berlakunya putusan MK No69/PUU-XII/2015?

2. Bagaimanakah model perjanjian kawin yang dibuat setelah berlakunya putusan MK No69/PUU-XII/2015?

\section{B. Metode Penelitian}

Metode yang digunakan dalam penelitian ini dilakukan melaluiu pendekatan yuridis normatif dan spesifikasi penelitian secara deskriptif analitis. Pengumpulan data dilakukan melalui penelurusan data sekunder dan data primer sebagai data pendukung, dan selanjutnya data sekunder dan data primer di analisis secara yuridis kualitatif.

\section{Hasil dan Pembahasan}

\section{Pengaturan Mengenai Perjanjian} Kawin Setelah Berlakunya Putusan MK No69/PUU-XII/2015

Pembuatan perjanjian perkawinan saat ini semakin popular. Lembaga perkawinan merupakan hal yang sifatnya sangat individual, tetapi dewasa ini pasangan suami-isteri ingin menentukan persyaratan ekonomi dalam perkawinannya (Atwood,Barbara A. and Bix, 2012). Perjanjian kawin dibuat oleh seseorang orang-orang yang menginginkan 
pemelirahaan terhadap harta pribadinya, dimana perjanjian tersebut dibuat sebelum mereka menikah (Katz, 2003). Perjanjian kawin akan berlaku dan mengikat kedua pihak apabila dalam proses negosiasi dan persyaratan yang dibuat secara adil dan didasarkan pada kesepakatan diantara kedua pihak (Katz, 2003). Perjanjian kawin berisi perjanjian yang dibuat sebelum atau setelah perkawinan yang berisi tentang konsekuensi pemisahan harta apabila perkawinan putus karena perceraian atau karena kematian (Cooke, Elizabeth; Clarke, 2014).

Penyimpangan terhadap pengaturan harta benda dalam perkawinan dapat dilakukan dengan membuat perjanjian perkawinan yang berisi kesepakatan yang dibuat oleh calon suami isteri sebelum atau pada saat perkawinan dilangsungkan. Tetapi akhir-akhir ini kita dikejutkan dengan aturan yang membolehkan bahwa perjanjian perkawinan dapat dibuat selama perkawinan berlangsung. Dalam arti kata bahwa perjanjian perkawinan dapat dilakukan kapan saja oleh suami isteri dalam perkawinan seperti yang diatur dalam Putusan Mahkamah Konstitusi (Judiasih, 2017b).

Pada dasarnya Putusan Mahkamah Konstitusi tersebut telah merubah norma dan tatanan perjanjian perkawinan yang terdapat dalam Pasal 29 UUP, sehingga substansi Pasal 29 berubah menjadi sebagai berikut:
1. Pasal 29 ayat (1) Undang-Undang Nomor 1 Tahun 1974 tentang Perkawinan (Lembaran Negara Republik Indonesia Tahun 1974 Nomor 1, Tambahan Lembaran Negara Republik Indonesia Nomor 3019) bertentangan dengan Undang-Undang Dasar Negara Republik Indonesia Tahun 1945 sepanjang tidak dimaknai "Pada waktu, sebelum dilangsungkan atau selama dalam ikatan perkawinan kedua belah pihak atas persetujuan bersama dapat mengajukan perjanjian tertulis yang disahkan oleh pegawai pencatat perkawinan atau notaris, setelah mana isinya berlaku juga terhadap pihak ketiga sepanjang pihak ketiga tersangkut";

2. Pasal 29 ayat (1) Undang-Undang Nomor 1 Tahun 1974 tentang Perkawinan (Lembaran Negara Republik Indonesia Tahun 1974 Nomor 1, Tambahan Lembaran Negara Republik Indonesia Nomor 3019) tidak mempunyai kekuataan hukum mengikat sepanjang tidak dimaknai "Pada waktu, sebelum dilangsungkan atau selama dalam ikatan perkawinan kedua belah pihak 
atas persetujuan bersama dapat mengajukan perjanjian tertulis yang disahkan oleh pegawai pencatat perkawinan atau notaris, setelah mana isinya berlaku juga terhadap pihak ketiga sepanjang pihak ketiga tersangkut";

3. Pasal 29 ayat (3) Undang-Undang Nomor 1 Tahun 1974 tentang Perkawinan (Lembaran Negara Republik Indonesia Tahun 1974 Nomor 1, Tambahan Lembaran Negara Republik Indonesia Nomor 3019) bertentangan dengan Undang-Undang Dasar Negara Republik Indonesia Tahun 1945 sepanjang tidak dimaknai "Perjanjian tersebut mulai berlaku sejak perkawinan dilangsungkan, kecuali ditentukan lain dalam Perjanjian Perkawinan";

4. Pasal 29 ayat (3) Undang-Undang Nomor 1 Tahun 1974 tentang Perkawinan (Lembaran Negara Republik Indonesia Tahun 1974 Nomor 1, Tambahan Lembaran Negara 3019) tidak mempunyai kekuatan hukum mengikat sepanjang tidak dimaknai "Perjanjian tersebut mulai berlaku sejak perkawinan dilangsungkan, kecuali ditentukan lain dalam Perjanjian Perkawinan”;
5. Pasal 29 ayat (4) Undang-Undang Nomor 1 Tahun 1974 tentang Perkawinan (Lembaran Negara Republik Indonesia Tahun 1974 Nomor 1, Tambahan Lembaran Negara Republik Indonesia Nomor 3019) bertentangan dengan Undang-Undang Dasar Negara Republik Indonesia Tahun 1945 sepanjang tidak dimaknai "Selama perkawinan berlangsung, perjanjian perkawinan dapat mengenai harta perkawinan atau perjanjian lainnya, tidak dapat diubah atau dicabut, kecuali bila dari kedua belah pihak ada persetujuan untuk mengubah atau mencabut, dan perubahan atau pencabutan itu tidak merugikan pihak ketiga";

6. Pasal 29 ayat (4) Undang-Undang Nomor 1 Tahun 1974 tentang Perkawinan (Lembaran Negara Republik Indonesia Tahun 1974 Nomor 1, Tambahan Lembaran Negara Republik Indonesia Nomor 3019) tidak mempunyai kekuatan hukum mengikat sepanjang tidak dimaknai "Selama perkawinan berlangsung, perjanjian perkawinan dapat mengenai harta perkawinan atau perjanjian lainnya, tidak dapat 
diubah atau dicabut, kecuali bila dari kedua belah pihak ada persetujuan untuk mengubah atau mencabut, dan perubahan atau pencabutan itu tidak merugikan pihak ketiga".

\section{Model Perjanjian Kawin Yang Dibuat Setelah Berlakunya Putusan MK No69/PUU-XII/2015}

Perjanjian kawin yang dibuat setelah berlakunya Putusan Mahkamah Konstitusi Nomor 69/PUU-XIII/2015 dapat memuat perjanjian kawin terkait dengan harta perkawinan maupun dengan perjanjian lainnya. Perjanjian perkawinan menurut Pasal 29 ayat (4) putusan MK 69/2015 dapat mengenai harta perkawinan atau perjanjian lainnya, sehingga dengan demikian oleh para pihak dapat bebas menentukan isi perjanjian perkawinan tersebut diantaranya yang perlu diperhatikan adalah hal-hal sebagai berikut (Budiono, 2017):

Apabila oleh suami-isteri dibuat perjanjian perkawinan sepanjang perkawinan sedangkan perjanjian tersebut dinyatakan berlaku sejak saat perkawinan maka telah ada harta campur yang terbentuk. Dalam situasi seperti itu menjadi sulit untuk membagi harta campur tersebut maka sebaiknya dianjurkan agar sejak saat perkawinan hingga tanggal perjanjian perkawinan dibuat tetap merupakan harta campur sedangkan sejak perjanjian perkawinan terjadi pisah harta. Hal tersebut terlebih lagi apabila ada benda yang telah diagunkan pada bank yang apabila dilakukan pembagian diantara suami-isteri dapat merugikan pihak bank.

Dibagikannya bagian dari harta campur yang lebih besar kepada salah satu pihak, misalnya isteri mendapat 3/4 (tiga perempat) bagian dan suami $1 / 4 \quad$ (satu perempat) bagian, Pembagian tersebut berarti telah terjadi pergeseran harta diantara suami istri yang dapat digolongkan sebagai hibah, sedangkan hibah diantara suami istri selama perkawinan dilarang undang-undang, kecuali hadiah atau pemberian benda bergerak bertubuh yang harganya tidak terlalu tinggi mengingat kemampuan si penghibah (Pasal 1678 KUHPerd);

Menurut doktrin membagikan dan memisahkan harta perkawinan tidak dapat dilakukan atas persetujuan bersama karena tidak adanya alasan untuk melakukannya berkaitan dengan pemilikan bersama yang terikat. Pemilikan bersama yang terikat baru dapat diakhiri karena meninggalnya suami atau isteri atau perceraian suami isteri.

- $\quad$ Tidak dapat diperjanjikan, bahwa salah satu pihak akan menanggung hutang yang lebih 
besar daripada bagiannya dalam laba persatuan, yang menurut Asser-De Boer ketentuan tersebut batal demi hukum (de Boer, 2001);

- Untuk perjanjian perkawinan yang dinyatakan berlaku sejak perkawinan dilangsungkan sebaiknya dibuat daftar harta mana yang telah dimiliki sebelum dibuatnya perjanjian perkawinan yang ditandatangani suami-isteri dan dilekatkan pada minuta;

- Apabila pencantuman atas benda tidak dicantumkan dalam minuta maka atas penambahan benda yang ternyata diluar pengetahuan pihak yang bersangkutan dapat dibuktikan dengan cara lainnya. Apabila dikemudian hari timbul perselisihan mengenai kepemilikan atas benda yang tidak dapat dibuktikan tersebut, akan dianggap sebagai milik para pihak masing-masing untuk bagian yang sama besar. Anggapan tersebut tidak boleh merugikan para kreditor dari pasangan tersebut;

- Ada kemungkinan diperjanjikan berlakunya perjanjian perkawinan dengan ketentuan bersyarat baik dengan syarat menangguhkan atau dengan syarat membatalkan demikian pula dengan ketetapan waktu atau termin (termijn). Syarat menangguhkan bergantung pada peristiwa yang masih akan datang dan yang masih belum tentu akan terjadi, perikatan tidak dapat dilaksanakan sebelum peristiwanya belum terjadi. Syarat batal apabila dipenuhi menghentikan perikatan dan membawa segala sesuatu kembali pada keadaan semula, seolah-olah tidak pernah ada suatu perikata (Pasal 1253 KUHPerd). Ketetapan waktu (termin) tidak menangguhkan perikatan, melainkan hanya menangguhkan pelaksanaannya dan memberi kepastian kepada pihak ketiga bahwa prestasi pasti akan dilakukan pada waktu yang telah dijanjikan (Pasal 1268 KUHPerd). Misalnya, perjanjian perkawinan berlaku apabila telah dilahirkan seorang anak. Menurut Van Den Burght demikian juga Asser-De Boer, ketentuan demikian daya kerjanya terhadap pihak ketiga menimbulkan ketidak pastian sehingga harus dianggap bahwa perjanjian perkawinan tersebut batal, sedangkan daya kerja internal antara suami istri dapat 
berlaku sebagai perjanjian

obligatoir (de Boer, 2001).

Dengan demikian, terhadap pihak

ketiga dianggap diantara suami istri terjadi perkawinan dengan harta campur.

- Perjanjian perkawinan tidak boleh menunjuk berlakunya perundangundangan asing sebagai pilihan hukumnya.

- $\quad$ Tidak boleh mengurangi segala hak disandarkan pada kekuasaan suami dan kekuasaan orang tua, juga hak yang diberikan undangundang kepada suami-isteri yang hidup terlama;

Tidak boleh melepaskan hak yang diberikan undang-undang kepada mereka atas harta peninggalan keluarga sedarah mereka dalam garis ke bawah, pun tidak boleh mengatur harta peninggalan itu.

Hal lain yang harus diperhatikan dalam pembuatan perjanjian kawin yang dilakukan setelah perkawinan berlangsung meliputi antara lain hal-hal sebagai berikut (Judiasih, 2017a) :

1) Terhadap perjanjian perkawinan yang dibuat selama perkawinan berlangsung, maka perjanjian perkawinan harus dibu-at oleh notaris dan minta penetapan dari pengadilan.

2) Harta bersama yang sedang dijadikan objek jaminan kredit harus dikecualikan dalam perjanjian, dengan kata lain, har-ta yang sedang dijadikan objek jaminan kredit, harus tetap dibiarkan sebagai harta bersama yang tidak dapat beralih atau berubah status menjadi jenis harta lain selain tetap sebagai harta bersama. Hal ini dimaksudkan sebagai bentuk per-lindungan hukum terhadap pihak ketiga sehingga akan terjamin kepastian pem-bayaran dan pemenuhan kewajiban dari suami istri sebagai debitur.

3) Perjanjian perkawinan yang dibuat sela-ma perkawinan berlangsung hanya meli-puti harta-harta yang diperoleh setelah perjanjian perkawinan dibuat, jadi tidak meliputi harta-harta yang sudah ada sebelum perjanjian perkawinan dibuat.

4) Perjanjian perkawinan yang dibuat sela-ma perkawinan berlangsung, berlaku sejak perjanjian tersebut dibuat, jadi perjanjian perkawinan tersebut tidak berlaku surut.

5) Perjanjian perkawinan yang dibuat sela-ma perkawinan berlangsung perlu dibuat model/bentuk/format perjanjian yang memperhatikan 
norma, etika dan itikad baik, sehingga dapat terwujud keadilan dan kepastian hukum bagi para pihak yang berkepentingan.

6) Harus diperhatikan jangka waktu perkawinan yang diperbolehkan untuk membuat perjanjian kawin.

Terkait dengan pembuatan perjanjian kawin selama perkawinan berlangsung, Dinas Kependudukan dan Pencatatan Sipil Kota Bandung berkonsultasi dengan Sub Direktorat Pencatatan Perkawinan dan Perceraian Direktorat Pencatatan Sipil mengenai permasalahan bagaimana tindakan aparat pencatatan sipil di daerah menyikapi perjanjian perkawinan yang dilaksanakan setelah terbitnya Putusan Mahkamah Konstitusi Nomor 69/PUU-XIII/2015 Tahun 2015, diinformasikan bahwa Direktur Jenderal Administrasi Kependudukan dan Pencatatan Sipil Kementerian Dalam Negeri akan mengeluarkan Surat Edaran berkaitan mengenai Prosedur, Persyaratan dan Tatacara Pelaporan Pencatatan Perjanjian Perkawinan, baik sebelum atau pada saat perkawinan (prenuptial agreement) atau pencatatan perjanjian perkawinan setelah/selama perkawinan berlangsung (postnuptial agreement), namun demikian sampai hari ini Surat Edaran dimaksud belum ada realisasinya. Disdukcapil Kota Bandung mencatat bahwa pada tahun 2016 terdapat pencatatan perkawinan WNI sebanyak 1187 pemohon dan WNA sebanyak 13 pemohon. Dari jumlah tersebut yang memproses perjanjian kawin berjumlah 76 pemohon (Sugiharto, 2017).

Menindaklanjuti Putusan Mahkamah Konstitusi Republik Indonesia Nomor: 69/PUU-XIII/2015 tangggal 27 Oktober 2016, Direktorat Jendral Kependudukan dan Pencatatan Sipil mengeluarkan Surat Edaran tertanggal 19 Mei 2017 Nomor 472.2/5876/Dukcapil, perihal Pencatatan Pelaporan Perjanjian Perkawinan, menyampaikan beberapa hal sebagai berikut:

1. Perjanjian perkawinan dapat dibuat sebelum, pada saat dan selama perkawinan berlangsung dengan akta notaris dan dilaporkan kepada Instansi Pelaksana atau Unit Pelaksana Teknis (UPT) Instansi Pelaksana.

2. Persyaratan dan tata cara pencatatan atas pelaporan perjanjian perkawinan serta perubahan perjanjian perkawinan atau pencabutan perjanjian perkawinan, sebagaimana dimaksud pada Lampiran I.

3. Terhadap pelaporan perjanjian perkawinan sebagaimana dimaksud pada angka 1, Pejabat Pencatatan Sipil pada Instansi Pelaksana atau UPT Instansi Pelaksana membuat catatan pinggir pada registrasi akta dan kutipan 
akta perkawinan sebagaimana format pada Lampiran II A dan II B.

4. Khusus untuk akta perkawinan atau dengan nama lain yang diterbitkan oleh Negara lain, tetapi perjanjian perkawinan atau perubahan dan pencabutannya dibuat di Indonesia, pencatatan pelaporan perjanjian perkawinan dimaksud dibuat dalam bentuk surat keterangan sebagaimana format pada Lampiran III A dan III B.

Di dalam Lampiran surat edaran tersebut, dijelaskan mengenai persyaratan dan tata cara pencatatan pelaporan perjanjian perkawinan yang dapat diperinci sebagai berikut:

1. Pencatatan pelaporan perjanjian perkawinan dilakukan dengan memperhatikan:

a. Perjanjian perkawinan dibuat pada waktu atau sebelum dilangsungkan perkawinan;

b. Perjanjian perkawinan dibuat selama dalam ikatan perkawinan;

c. Perjanjian perkawinan dibuat di Indonesia dan pencatatan perkawinannya dilakukan di Negara lain;

d. Perubahan atau pencabutan perjanjian perkawinan.

2. Pencatatan pelaporan perjanjian perkawinan sebagaimana dimaksud pada angka 1 huruf a dilakukan dengan persyaratan:
a. Foto copy KTP-el;
b. Foto copy KK;
c. Akta Notaris Perjanjian Perkawinan yang telah dilegalisir dengan menunjukkan aslinya.

d. Foto copy akta notaris perjanjian perkawinan yang telah dilegalisir dengan menunjukan aslinya;
e. Kutipan akta perkawinan suami dan isteri.

3. Pencatatan pelaporan perjanjian perkawinan sebagaimana dimaksud pada angka 1 huruf $b$ dilakukan dengan persyaratan:
a. Foto copy KTP-el;
b. Foto copy KK;
c. Foto copy akta notarus perjanjian perkawinan yang telah dilegalisir dengan menunjukan aslinya;
d. Kutipan akta perkawinan suami dan isteri.

4. Pencatatan pelaporan perjanjian perkawinan sebagaimana dimaksud pada angka 1 huruf $\mathrm{c}$ dilakukan dengan persyaratan:
a. Foto copy KTP-el;
b. Foto copy KK;
c. Foto copy akta notaris perjanjian perkawinan yang telah dilegalisir dengan menunjukan aslinya; 
d. Kutipan akta perkawinan atau dengan nama lain yang diterbitkan oleh Negara lain;

e. Surat keterangan pelaporan akta perkawinan yang diterbitkan oleh Negara lain.

5. Pencatatan pelaporan perjanjian perkawinan sebagaimana dimaksud pada angka 1 huruf d dilakukan dengan memenuhi persyaratan:

a. Foto copy KTP-el;

b. Foto copy KK;

c. Foto copy akta notaris perjanjian perkawinan yang telah dilegalisir dengan menunjukan aslinya;

d. Kutipan akta perkawinan atau dengan nama lain yang diterbitkan oleh Negara lain;

e. Surat keterangan pelaporan akta perkawinan yang diterbitkan oleh Negara lain.

6. Pencatatan pelaporan perjanjian perkawinan sebagaimana dimaksud pada angka 1 huruf $a, b, c$ dan $d$ dilakukan dengan tata cara:

a. Pasangan suami dan/atau isteri menyerahkan persyaratan sebagaimana pada angka 2, 3, 4 dan 5;

b. Pejabat Pencatatan Sipil pada UPT Instansi Pelaksana atau Instansi Pelaksana membuat catatan pinggir pada register akta dan kutipan akta perkawinan atau menerbitkan Surat Keterangan bagi perjanjian perkawinan yang dibuat di Indonesia dan pencatatan perkawinannya dilakukan di Negara lain;

c. Kutipan akta perkawinan yang telah dibuatkan catatan pinggir atau Surat Keterangan diberikan kepada masing-masing suami dan/atau Isteri. 
Adapun format pencatatan perjanjian kawin berdasarkan surat edaran dari Dirjen Dukcapil tersebut dapat dlihat dalam contoh dibawah ini

II A. Format Catatan Pinggir Perjanjian Perkawinan pada Register Akta dan Kutipan Akta Perkawinan

\section{CATATAN PINGGIR \\ PERJANJIAN PERKAWINAN \\ PADA REGISTER DAN KUTIPAN AKTA PERKAWINAN}

Berdasarkan akta perjanjian perkawinan Nomor.... tanggal.... bulan.... tahun..... yang dibuat di hadapan Notaris...... yang berkedudukan di...... telah mengadakan kesepakatan bersama atas perjanjian perkawinan sebagai lampiran dalam akta perkawinan.

Pejabat Pencatatan Sipil

NIP. 
II B. Format Catatan Pinggir Perubahan/Pencabutan Perjanjian Perkawinan pada Register Akta dan Kutipan Akta Perkawinan

\section{CATATAN PINGGIR \\ PERUBAHAN/PENCABUTAN *) PERJANJIAN PERKAWINAN PADA REGISTER DAN KUTIPAN AKTA PERKAWINAN}

Berdasarkan akta perjanjian perkawinan Nomor..... tanggal..... bulan... tahun.... yang dibuat di hadapan Notaris.... yang berkedudukan di..... telah dilakukan perubahan/pencabutan*) atas akta perjanjian perkawinan Nomor... tanggal.... bulan.... tahun... yang dibuat di ahadapan Notaris..... yang berkedudukan di..... sebagai lampiran dalam akta perkawinan.

Pejabat Pencatatan Sipil

NIP.

Lampiran III: Surat Direktur Jendral Kependudukan dan Pencatatan Sipil

III A. Format Surat Keterangan Pelaporan Perjanjian Perkawinan Sebagai Lampiran Akta Perkawinan Atau Dengan Nama Lain Yang Diterbitkan Oleh Negara Lain.

\section{KOP SURAT DINAS}

\section{SURAT KETERANGAN PELAPORAN PERJANJIAN PERKAWINAN}

Berdasarkan akta perkawinan atau dengan nama lain yang diterbitkan oleh Negara... Nomor.... tanggal...... bulan...tahun.... telah dilaporkan akta perjanjian perkawinan Nomor.... tanggal... bulan.... tahun.... yang dibuat di hadapan Notaris.... yang berkedudukan di.... sebagai lampiran dalam akta perkawinan atau dengan nama lain dan surat keterangan pelaporan perkawinan yang diterbitkan oleh Negara lain.

Pejabat Pencatatan Sipil

NIP. 
III B. Format Surat Keterangan Pencatatan Perubahan/Pencabutan Pelaporan Perjanjian Perkawinan Sebagai Lampiran Akta Perkawinan Atau Dengan Nama Lain Yang Diterbitkan Oleh Negara Lain.

\section{KOP SURAT DINAS}

\section{SURAT KETERANGAN PENCATATAN PERUBAHAN/PENCABUTAN PELAPORAN PERJANJIAN PERKAWINAN}

Berdasarkan akta perjanjian perkawinan Nomor... tanggal.... bulan.... tahun... yang dibuat di hadapan Notaris...... yang berkedudukan di....... bahwa Notaris.... yang berkedudukan di.... bahwa sesuai akta perkawinan atau dengan nama lain yang diterbitkan oleh Negara.... Nomor... tanggal... bulan... tahun.... telah dilakukan perubahan/pencabutan*) atas akta perjanjian perkawinan Nomor.... tanggal... bulan... tahun... yang dibuat di hadapan Notaris... yang berkedudukan di... sebagai lampiran dalam akta perkawinan atau dengan nama lain dan surat keterangan pelaporan perkawinan yang diterbitkan oleh Negara lain.

Pejabat Pencatatan Sipil

Nip. 


\section{Simpulan dan Saran}

Berdasarkan hasil analisis dari babbab sebelumnya dapat disimpulkan bahwa Pengaturan mengenai perjanjian kawin setelah keluarnya putusan Mahkamah Konstitusi Nomor 69/PUU-XIII/2015 menentukan bahwa perjanjian kawin dapat dibuat sebelum, pada saat dan selama perkawinan berlangsung. Terdapat beberapa format dari model perjanjian kawin yang dapat menjadi panduan bagi para notaris yang akan membuat akta perjanjian kawin dan terdapat pula surat edaran dari Dirjen Dukcapil terkait Pencatatan Pelaporan Perjanjian Perkawinan.

\section{DAFTAR PUSTAKA}

Atwood,Barbara A. and Bix, B. H. (2012). A New Uniform Law For Premartial and Marital Agreements. Family Law Quarterly, 46(3), 313.

Budiono, H. (2017). Perjanjian Perkawinan Pasca Putusan Mahkamah Konstitusi Nomor 69 Tahun 2015 dan Permasalahannya. In Loka Karya Perjanjian Perkawinan Pasca Putusan MK 69/2015. Bandung: Universitas Padjadjaran.

Cooke, Elizabeth; Clarke, S. (2014). The Law Commisions Report on Matrimonial Property, Needs and Agremeents. Family Law Quarterly,
48(2), 362.

Crotyy, P. M. (1999). Family Law in United States Changing Perspectives. Peter Lang Publishing.

de Boer, C. A.-J. (2001). Personen -en Familierecht, zestiende druk. Amsterdam: Kluwer-Deventer.

Judiasih, S. D. (2017a). Pertaruhan Esensi Itikad Baik dalam Pembuatan Perjanjian Kawin Pasca Putusan Mahkamah Konstitusi Nomor 69/PUU-XIII/2015. Jurnal Notariil, 1(2), 82-83.

Judiasih, S. D. (2017b). Quo Vadis Putusan Mahkamah Konstitusi Nomor 69/PUU-XIII/2015 tentang Perjanjian Kawin. In Lokakarya Perjanjian Kawin Pasca Putusan Mahkamah Konstitusi Nomor 69/PUU-XIII/2015. Departemen Hukum Keperdataan Fakultas Hukum Universitas Padjadjaran Bandung.

Katz, S. N. (2003). Family Law in America. New York: Oxford University Press.

Li, L. (2014). Be Prepared in Advance: A Case For Allowing Binding Prenuptial Agreementd in Hongkong. International Journal of Law, Policy and The Family, 28(3), 340.

Sugiharto. (2017). Pelaksanaan Pencatatan Perjanjian Perkawinan Pasca Putusan MK Nomor 69/PUU-XIII/2015 di Dinas Kependudukan dan Pencatatan 
Sipil Kota Bandung. In Loka Karya Perjanjian Perkawinan Pasca Putusan MK 69/2015. Bandung: Universitas Padjadjaran.
Walker, L. M. (2015). Family Law and Public Policy. Amsterdam: Wolters Kluwer. 